\title{
The Brachyura and Anomura fauna (Decapoda; Crustacea) in the Arvoredo Marine Biological Reserve on the southern brazilian coast
}

\author{
Bouzon, JL.* and Freire, AS.* \\ Departamento de Ecologia e Zoologia, Centro de Ciências Biológicas, Universidade Federal de Santa Catarina - UFSC, \\ Trindade, CEP 88010-970, Florianópolis, SC, Brazil \\ *e-mail: jbouzon@ccb.ufsc.br, andreasfreire@yahoo.com.br
}

Received May 3, 2005 - Accepted October 17, 2005 - Distributed May 31, 2007

(With 1 figure)

\begin{abstract}
Eight species of Brachyura and two species of Anomura were registered for the first time on the Santa Catarina coast, in the waters around the Arvoredo Marine Biological Reserve. The animals were collected by scuba divers, between 3 and 22 meters depth, from September 2001 to February 2003. A total of 31 decapod species were collected, and most of the new occurrences had already been registered in the adjacent northern waters.
\end{abstract}

Keywords: Arvoredo Island, Decapoda, occurrence, Santa Catarina, SCUBA dive.

\section{A fauna de Brachyura e Anomura (Decapoda; Crustacea) na Reserva Biológica Marinha do Arvoredo, costa sul brasileira}

\begin{abstract}
Resumo
Oito espécies de Brachyura e duas espécies de Anomura foram registradas pela primeira vez na costa de Santa Catarina, em águas no entorno da Reserva Biológica Marinha do Arvoredo. Os animais foram coletados por meio de mergulho autônomo, entre 3 e 22 metros de profundidade, de setembro 2001 a fevereiro de 2003. Um total de 31 espécies de Decapoda foram coletadas e a maioria das novas ocorrências já haviam sido registradas em águas adjacentes ao norte da Reserva.
\end{abstract}

Palavras-chave: Ilha do Arvoredo, Decapoda, ocorrência, Santa Catarina, SCUBA.

\section{Introduction}

The review of Lana et al. (1996) showed that benthic crustaceans were poorly studied on the Santa Catarina coast. A complex current, wind and water mass interaction improves the transport of organisms from tropical, subtropical or even subantarctic areas to the southern coast (Borzone et al., 1999). The species diversity in the Arvoredo Archipelago is the result of the occurrence of tropical and subtropical fauna and recent works have been quantifying these species. Among the ten species of sponges that occurred in the area, four were registered for the first time on the Brazilian coast (Lerner, 1996). In addition, seventeen mollusk species were registered for the first time on the Santa Catarina coast (Wiggers and Magalhaes, 2003). The unique coralline red algal bed (Corallinaceae, Rhodophyta) of the Brazilian southern coast occurs in the main island, where 5 non articulated coralline algae species were registered for the first time in southern waters (Horta, 2000).

There is no scientific report about the crustaceans of the Arvoredo Biological Marine Reserve (Reserva Biológica Marinha do Arvoredo, RBMA) (27 17' 7" S and $48^{\circ} 25^{\prime} 30^{\prime \prime} \mathrm{W}$ ). However, fishermen and divers usually find shrimps, crabs and lobsters which are illegally captured in the area.

The present work aims to survey the fauna of Brachyura and Anomura in the Arvoredo Biological Marine Reserve. The management plan of the marine reserve has been established after our samplings. It would be possible from now on to follow the changes in the species richness after the improvement of the new activites in the area.

\section{Material and Methods}

The studied area is close to the Subtropical Convergence (33-38 S), where the Brazilian Current flowing to the south reaches the Malvinas Current, which flows to the north. The South Atlantic Central Water (SACW) is formed in the area of the Convergence and circulates in the South Atlantic Ocean (Silveira et al., 2001). In the Arvoredo Archipelago area the SACW occurs at $20 \mathrm{~m}$ depth and the Tropical Shelf Water dominates the surface waters (Chludinski and Bonetti, 2002). 
Crustaceans were surveyed from September 2001 to February 2003 at 5 different sites around the Arvoredo Island (Figure 1). Most of the sampling was conducted in the Rancho Norte site, over the coralline algal bed. The animals were collected from 3 to $22 \mathrm{~m}$ depth through scuba diving, in fifteen different expeditions. Water temperature and salinitiy were also recorded. The crustaceans were sought by two divers over the sand, under rocks, inside crevices, inside and over the rhodoliths (free-living forms of non-geniculate coralline red algae), in the middle of macroalgae, and collected and maintained in seawater aquariums. Only three individuals of each species were allowed to be captured by the local environmental agency (IBAMA). The animals were anesthetized with $2 \%$ magnesium chloride, fixed with $70 \%$ ethyl alcohol, identified and had their range distribution described according to Gomes-Correa (1999), Martins and D`incao (1996), Melo (1996, 1999a, 1999b), Veloso (1999) and Young (1998). The specimens were deposited in the Departamento de Ecologia e Zoologia Collection of Crustacea of the Universidade Federal de Santa Catarina (LCP/UFSC 001, 002, 003, 004, 005, 008, 009, 010, 011, 013, 014, 015, 016, 017, 018, 019, 020, 021, 022, 023, 024, 025, 026, 027, 028, 029, 030, 031, 032, 033, 034, 035, 036).

\section{Results and Discussion}

Salinity and temperature data varied from 30 to $36.5 \%$ and 16.5 to $23{ }^{\circ} \mathrm{C}$, characterizing the presence of Tropical Water and South Atlantic Central Water or Subtropical Water (Emilson, 1959).

A total of thirty one species were collected in the area (Table 1), being 2 Paguridae, 2 Diogenidae and 2 Porcellanidae (Anomura) and most of the Brachyura were Majidae and Xanthidae. Five species of Majidae, one Goneplacidae, one Dromiidae, one Pinnotheridae, one Paguridae and one Diogenidae, comprising 10 spe- cies, were registered for the first time on the Santa Catarina coast, in the waters around the Arvoredo Marine Biological Reserve (Table 1).

According to the crustacean biogeographic division of South America, Arvoredo Island is located in the Paulista Province (Coelho et al., 1980). Eight species had been previously registered up to São Paulo (Melo, 1996), in the Paulista Province and one in Espírito Santo, which is in the Brazilian Zoogeographic Province (Coelho, op. cit.) and now have their distribution expanded to Santa Catarina. Paguristes robustus Forest and Saint Laurent, 1967, was previously recorded in the Argentinean Province; this occurrence should be related to the influence of the cold waters in the area.

Costa (1968) apud Palácio (1982), working with Brachyura, showed a faunistic change between the Abrolhos Archipelago and Cape Frio and another change between São Paulo and Santa Catarina. Patterns of marine species distributions are influenced and limited by frontiers that are very difficult to detect (Melo, 1985). The new occurrence of these species in the Arvoredo area, close to septentrional limit of the tropical fauna of the Paulista Province and the northern limit of the Argentinean Province was already expected with the increase of the samplings.

Marine invertebrate surveys along the Brazilian coast are mainly conducted from otter trawls of fishing boats, oceanographic vessels or snorkeling. Eighty six Brachyuran species and twenty seven Anomuran species have already been complied by Melo (1996 and 1999) on the Santa Catarina coast and could be found around Arvoredo Island. However, scuba sampling efforts improve the capture of hidden animals in crevices or under rocks. Some species, including some of the new records (Table 2), were collected associated to the rhodoliths. The presence of the rhodoliths was the main force to the structure of the benthic macrofauna community in the algal bed of the

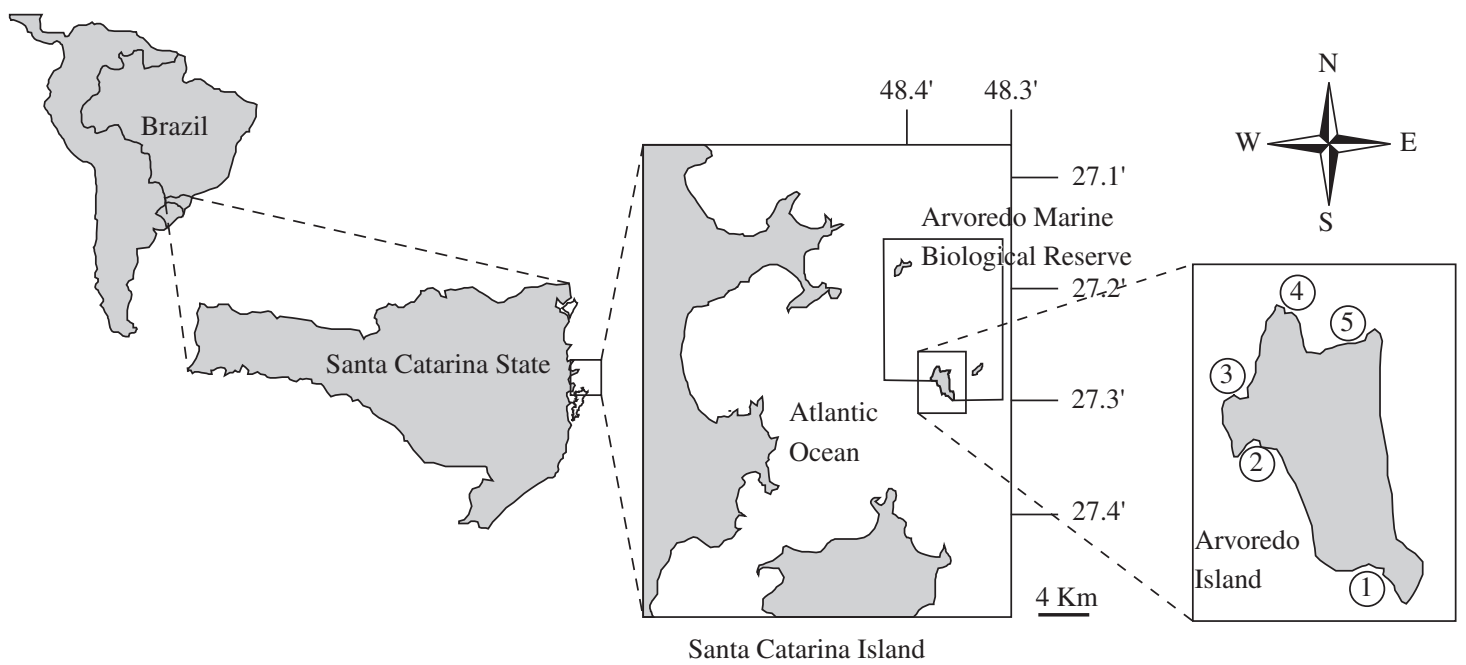

Figure 1. Study area showing the position of the Arvoredo Marine Biological Reserve and the sampling stations: 1) Baía do Farol; 2) Saco do Capim; 3) Rancho Norte; 4) Ponta do Letreiro; and 5) Saco d' Água. 
Table 1. Decapods registered in the area of Arvoredo Island $\left(27^{\circ} 17^{\prime} 7^{\prime \prime} \mathrm{S}\right.$ and $\left.48^{\circ} 25^{\prime} 30^{\prime \prime} \mathrm{W}\right)$, new occurrences in Santa Catarina and previous distribution along the Brazilian coast.

\begin{tabular}{|c|c|c|c|}
\hline $\begin{array}{c}\text { Infraorder and } \\
\text { Family } \\
\end{array}$ & Species & $\begin{array}{l}\text { New } \\
\text { record }\end{array}$ & Previous distribution \\
\hline \multicolumn{4}{|l|}{ ANOMURA } \\
\hline \multirow[t]{2}{*}{ Diogenidae } & Calcinus tibicen (Herbst, 1791) & $\mathrm{x}$ & $\begin{array}{l}\text { Fernando de Noronha and Ceará } \\
\text { to São Paulo }\end{array}$ \\
\hline & Dardanus arrosor insignis (de Saussure, 1858) & & $\begin{array}{l}\text { Rio de Janeiro to Rio Grande do } \\
\text { Sul }\end{array}$ \\
\hline Paguridae & $\begin{array}{l}\text { Paguristes robustus Forest and Saint Laurent, } 1967 \\
\text { Rhodochirus rosaceus (A. Milne Edwards and } \\
\text { Bouvier, 1893) }\end{array}$ & $\mathrm{x}$ & $\begin{array}{l}\text { Rio Grande do Sul to Argentina } \\
\text { São Paulo to Rio Grande do Sul }\end{array}$ \\
\hline Porcellanidae & $\begin{array}{l}\text { Minyocerus angustus (Dana, 1852) } \\
\text { Porcellana sayana (Leach, 1820) }\end{array}$ & & $\begin{array}{l}\text { Pará to Santa Catarina } \\
\text { Amapá to Rio Grande do Sul }\end{array}$ \\
\hline \multicolumn{4}{|l|}{ BRACHYURA } \\
\hline Calappidae & $\begin{array}{l}\text { Calappa gallus (Herbst, 1803) } \\
\text { Hepatus pudibundus Herbst, } 1785\end{array}$ & & $\begin{array}{l}\text { Alagoas to Rio Grande do Sul } \\
\text { Amapá to Rio Grande do Sul }\end{array}$ \\
\hline Dromiidae & Hypoconcha parasitica (Linnaeus, 1763) & $\mathrm{x}$ & Maranhão to São Paulo \\
\hline Goneplacidae & Neopilumnoplax americana (Rathbun, 1898) & $\mathrm{x}$ & Espírito Santo \\
\hline Grapsidae & Pachygrapsus transversus (Gibbes, 1850) & & $\begin{array}{l}\text { Ilha de Trindade and Ceará to } \\
\text { Rio Grande do Sul }\end{array}$ \\
\hline \multirow[t]{9}{*}{ Majidae } & Epialtus bituberculatus H. Milne Edwards, 1834 & $\mathrm{x}$ & Ceará to São Paulo \\
\hline & Macrocoeloma camptocerum (Stimpson, 1871) & $\mathrm{x}$ & $\begin{array}{l}\text { Fernando de Noronha and Piauí } \\
\text { to São Paulo }\end{array}$ \\
\hline & Mithraculus forceps (A. Milne Edwards, 1875) & $\mathrm{x}$ & $\begin{array}{l}\text { Fernando de Noronha, Atol das } \\
\text { Rocas and Maranhão to São } \\
\text { Paulo }\end{array}$ \\
\hline & Mithrax hispidus (Herbst, 1790) & & Pará to Santa Catarina \\
\hline & Mithrax tortugae Rathbun, 1920 & & Espírito Santo to Santa Catarina \\
\hline & Pelia rotunda (A. Milne Edwards, 1875) & & Pará to Rio Grande do Sul \\
\hline & Pitho lherminieri (Schramm, 1867) & $\mathrm{x}$ & $\begin{array}{l}\text { Fernando de Noronha and Pará } \\
\text { to São Paulo }\end{array}$ \\
\hline & Podochela algicola Stebbing, 1914 & $\mathrm{x}$ & Maranhão to São Paulo \\
\hline & Stenorhynchus seticornis (Herbst, 1788) & & Amapá to Rio Grande do Sul \\
\hline Parthenopidae & Heterocrypta tommasii Rodrigues da Costa, 1959 & & Ceará to Rio Grande do Sul \\
\hline Pinnotheridae & Tumidotheres maculatus (Say, 1818) & $\mathrm{x}$ & Alagoas to São Paulo \\
\hline Portunidae & Cronius ruber (Lamark, 1818) & & Amapá to Rio Grande do Sul \\
\hline \multirow[t]{8}{*}{ Xanthidae } & Cataleptodius floridanus Gibbes, 1850 & & $\begin{array}{l}\text { Atol das Rocas, Fernando de } \\
\text { Noronha and Ceará to Rio } \\
\text { Grande do Sul }\end{array}$ \\
\hline & Eurypanopeus abreviatus (Stimpson, 1860) & & Ceará to Rio Grande do Sul \\
\hline & Hexapanopeus paulensis Rathbun, 1930 & & Pará to Santa Catarina \\
\hline & Hexapanopeus schmitti Rathbun, 1930 & & Ceará to Santa Catarina \\
\hline & Menippe nodifrons Stimpson, 1859 & & Maranhão to Santa Catarina \\
\hline & Pilumnus diomedae Rathbun, 1894 & & Amapá to Rio Grande do Sul \\
\hline & Pilumnus reticulatus Stimpson, 1860 & & Pará to Rio Grande do Sul \\
\hline & Pilumnus spinosissimus Rathbun, 1898 & & $\begin{array}{l}\text { Rio Grande do Norte to Santa } \\
\text { Catarina }\end{array}$ \\
\hline
\end{tabular}

Arvoredo Island (Blankensteyn et al., 2003). We could not find other studies in the literature where only scuba-diving was used to sample crustaceans along the Brazilian coast. Crabs were in general very hard to find, especially dur- ing the day. Most of the time, after 50 minutes searching, we returned on board with two or three different species. There was almost one new record of decapod species in the area per dive (10 new records in 15 dives). 
Table 2. Location of the occurrence on the Arvoredo Island and ecological remarks on the new records of Anomura and Brachyura on the Santa Catarina coast.

\begin{tabular}{|c|c|c|}
\hline Species & Site & Habitat and ecological remarks \\
\hline Calcinus tibicen & Baía do Farol and Saco d'Água. & Over rhodoliths and rocks, easily observed \\
\hline Paguristes robustus & Saco do Capim and Rancho Norte & $\begin{array}{l}\text { Over the rocks and sand, associated to the } \\
\text { rhodoliths }\end{array}$ \\
\hline Epialtus bituberculatus & Baía do Farol and Rancho Norte & Associated to the macroalgae \\
\hline Mithraculus forceps & $\begin{array}{l}\text { Baía do Farol, Rancho Norte, Saco } \\
\text { do Capim and Saco d'Água }\end{array}$ & Very common inside the rhodoliths \\
\hline Pitho lherminieri & Rancho Norte & Over, under and inside the rhodoliths \\
\hline Podochela algicola & Baía do Farol & Associated to the macroalgae \\
\hline Neopilumnoplax americana & Rancho Norte & Over the sand, under the rocks \\
\hline Macrocoeloma camptocerum & Baía do Farol & Associated to the macroalgae \\
\hline Hypoconcha parasitica & Rancho Norte & $\begin{array}{l}\text { Moving during the night attached to a single } \\
\text { valve of the bivalve Chione pubera Bory Saint- } \\
\text { Vicent, } 1827\end{array}$ \\
\hline Tumidotheres maculatus & Baía do Farol & Associated to the macroalgae \\
\hline
\end{tabular}

Calappa gallus Herbst, 1803, was collected only during the night sample in the coralline red algae bed. Its carapace was completely encrusted with the coralline algae and the animals were moving fast over the rhodoliths. Calappa philargius Linnaeus, 1758, had also shown night activity along the eastern coast of Thailand and this behavior would prevent the algal encrustation (Becker and Wahl, 1996). However, epibiontic encrustation is also considered a positive interaction, like crab camouflage (Coutress et al., 1970 apud Becker and Wahl, 1996; Maldonado and Uriz, 1992). The pagurids Rhodochirus rosaceus A. Milne Edwards and Bouvier, 1893 and Dardanus arrosor Saussure, 1858, were freely moving during the day over the rhodoliths but only the shells inhabited by $R$. rosaceus had coralline algal encrustation.

Porcellana sayana Leach, 1820, has a symbiotic relationship with pagurids (Melo, 1999) and this species was registered on the shells inhabited by Dardanus arrosor insignis, and not in the abdomen as expected. Stenorhynchus seticornis Herbst, 1788, was easily observed, moving and jumping slowly under the rocks. Mithraculus forceps A. Milne Edwards, 1875, and Mithrax tortugae Rathbun, 1920, were very common inside the rhodoliths.

Scuba diving proved to be a very good option to sample the sea bottom without destruction of the whole environment and to search for animals hidden in microhabitats. Thus, amending the previous scarce sampling along the Santa Catarina coast, ten new records for the area have now been added, with the expansion of the distribution of these species.

Acknowledgments - We would like to thank the Sea Divers diving school, Projeto Larus/UFSC, Dr. Paulo Horta (Depto. Aquicultura/CCA/UFSC) and the Polícia Ambiental of Santa Catarina and IBAMA/SC for providing sampling facilities; Prof. Dr. Gustavo Melo (Museu de Zoologia/USP) for the review of the identification of the Brachyura; Prof. Guisla Boehs (Depto. Aquicultura/CCA/UFSC) for the bivalve identification and
José Pedrassoli Salles (Depto. Aquicultura/CCA/UFSC) for the design of Figure 1.

\section{References}

BECKER, K. and WAHL, M., 1996. Behaviour Patterns as Natural Antifouling Mechanisms of Tropical marine crabs. $J$. Exp. Mar. Biol. Ecol., vol. 203, no. 2, p. 245-258.

BLANKENSTEYN, A., ALMEIDA, FS., GUIMARÃES, CF., BOUZON, JB., WEISS, LJ., CAMARGO, LM., TELLES, S. and FREIRE, AS., 2003. A macrofauna bentônica do banco de algas calcárias da Reserva Biológica Marinha do Arvoredo, SC, Brasil. In Anais do $2^{\circ}$ Simpósio de Áreas Protegidas. Anais... Conservação no Âmbito do Cone Sul. Universidade Católica de Pelotas, RS. p. 83-93.

BORZONE, CA., PEZZUTO, PR. and MARONE, E., 1999. Oceanographic Characteristics of a Multi-Specific Fishing Ground of the Central South Brazil Bight. Mar Ecol., vol. 20, no. 2, p. 131-146.

CHLUDINSKI, AP. and BONETTI FILHO, J., 2002. Aplicação de um Modelo Digital de Terreno na Caracterização do relevo submerso da Reserva Biológica Marinha do Arvoredo e Baía de Tijucas - SC. Gerenciamento Costeiro Integrado, vol. 1, no. 2, p. 13-14.

COELHO, PA., PORTO, MR. and KOENING, ML., 1980. Biogeografia e bionomia dos crustáceos do litoral equatorial brasileiro. Trab. Oceanogr. da Univ. Fed. PE, vol. 15, p. 7-138.

COSTA, HR. Crustácea Brachyura récoltés par lês dragages de la "Calypso" sur les côtes brésiliennes (1962). Recl Trav. Stn marine, 1968, vol. 59, no. 43, p. 333-343.

COUTRESS, C., ROSS, DM., and SUTTON, L., 1970. The Association of Calliactis tricolor with its pagurid, calappid and maijid partners in the Caribbean. Can J Zool., vol. 48, no. 2, p. 371-386.

GOMES-CORREA, MM., 1999. Ordem Stomatopoda. In Os Crustáceos do Rio Grande do Sul. BUCKUP, L. and BUCKUP, GB. (eds). Porto Alegre, Universidade/UFRGS, p. 144-164. 
HORTA, PA., 2000. Macroalgas do infralitoral do Sul e Sudeste do Brasil: Taxonomia e Biogeografia. Tese de Doutorado, Universidade de São Paulo, 301 p.

LANA, PC., CAMARGO, MG., BROGIM, R., ISAAC, V., 1996. O bentos da costa brasileira: avaliação crítica e levantamento bibliográfico (1858-1996). MMA, CIRM, FEMAR, Rio de Janeiro, 432 p.

LERNER, CB., 1996. Esponjas da Ilha da Galé, Reserva Marinha Biológica da Ilha do Arvoredo, Santa Catarina, Brasil (Porífera; Desmospongiae). Biociências, vol. 4, no. 2, p. 101-129.

MALDONADO, M. and URIZ, MJ., 1992. Relationship between sponges and crabs: patterns of epibiosis onInachus aguiarii (Decapoda: Majidae). Mar. Biol., vol. 113, no. 2, p. $81-286$.

MARTINS, STS. and D'INCAO, F., 1996. Os Pinnotheridae de Santa Catarina e Rio Grande do Sul, Brasil (Decapoda, Brachyura). Rev. Bras. Zool., vol. 13, no. 1, p. 1-26.

MELO, GAS., 1985. Taxonomia e padrões distribucionais $e$ ecológicos dos Brachyura (Crustacea: Decapoda) do litoral sudeste do Brasil. (Tese de Doutorado) - Universidade de São Paulo, 215 p.
-., 1996. Manual de identificação dos Brachyura (Caranguejos e siris) do litoral brasileiro. São Paulo, Plêiade, 640 p.

-., 1999a. Manual de identificação dos Crustacea Decapoda do litoral brasileiro: Anomura, Thalassinidea, Palinuridea, Astacidea. São Paulo, Plêiade/ FAPESP, 551 p.

-., 1999b. Infraordem Brachyura. In Os Crustáceos do Rio Grande do Sul. BUCKUP, L. and BUCKUP, GB. (eds). Porto Alegre, Universidade/UFRGS, p. 415-485.

PALÁCIO, FJ., 1982. Revisión Zoogeográfica Marina Del Sur Del Brasil. Bol. Inst oceanogr., vol. 31, no. 1, p. 69-92.

SILVEIRA, ICA., SCHMIDT, ACK., CAMPOS, EJD., GODOI, SS., IKEDA, Y., 2001. A corrente do Brasil ao largo da costa leste brasileira. Rev. bras. oceanogr., vol. 48, no. 2, p. 171-183.

VELOSO, VG., 1999. Família Porcellanidae. In Os Crustáceos do Rio Grande do Sul. BUCKUP, L. and BUCKUP, GB. (eds). Porto Alegre, Universidade/UFRGS, p. 398-405.

WIGGERS, F. and MAGALHÃES, AR., 2003. Novas ocorrências de moluscos marinhos na Reserva Biológica Marinha do Arvoredo. Biotemas, vol. 16, no. 1, p. 81-89.

YOUNG, PS., 1998. Catalogue of Crustacea of Brazil. Rio de Janeiro, Museu Nacional, 717 p. 
